\title{
THE EFFECT OF INVESTMENT IN EDUCATION ON SOCIO-ECONOMIC DEVELOPMENT OF PAKISTAN
}

\author{
Nayab Karim* \& Dr Farah Khan $\dagger$
}

\begin{abstract}
It is widely accepted that the education sector plays a vital role in the development of the economy and has a positive impact on the economic growth, this study is an attempt to explore the relationships among the investment in the human capital, physical capital and the school enrollment and its impact on the growth of Pakistan's economy. This study focus on time series analysis, the data has traced from World Development Indicators from 1980 to 2018. The empirical results showed that the investment in physical capital and school enrollment has a positive significant impact on the growth of Pakistan's economy. Therefore, the government of Pakistan should focus more on investment in education sector and thereby improve social prosperity.
\end{abstract}

Key words: Investment; education sector; economic development; Pakistan

\section{Introduction}

There can be no huge monetary development in any nation without sufficient interest in training. In the previous decades, for the most part amid the Pakistan autonomy, the arranging of Pakistan's economy was fixated on collection of physical capital and Natural assets for quick development and advancement without acknowledgment of essential jobs played by interest in

\footnotetext{
*MS, Pakistan Institute of Development Economics, Islamabad. Email: nayabkarim111@gmail.com

${ }^{\dagger}$ Assistant Professor, Women University Mardan, KP-Pakistan, Email: drfarah@wumardan.edu.pk
} 
instruction, as it improves human capital improvement. This should be coordinated into the arranging procedure with the end goal to accomplish a manageable monetary development and advancement. The economy of Pakistan was unquestionably aptitude obliged. Similarly undisputable is the noteworthy positive job that instruction plays in expanding the profitable limit of the individual and the general public, which contributes massively to the monetary development. Accordingly, the suggestion of the commission report was interest in training. This went for overhauling Pakistan and advancement of country's labor through instruction (essential, auxiliary and tertiary) which will supply the nation's labor requirements for the development of the economy. Educator Harbison's extraordinary investigate that the Pakistan labor this commission requires significant interest in training in order to guarantee monetary development. Interest in instruction is a procedure of human capital arrangement through obtaining aptitudes, capacities, The way toward expanding the quantity of individuals who have aptitudes, training and encounters are basic for the financial objective of the nation (Harbison, 1973). Instruction interest in human capital is in any event as vital as interest in physical capital for a district for quite some time run financial achievement (Mankiw, 1998).

The UNDP (2004) contends that development and advancement should center on human improvement through interest in training and wellbeing to serve the general population. On this premise, UNDP has advanced human improvement file (HDI) which incorporates the learning (Adult proficiency, joined enrolment proportion) through instruction. This requires the nation's pledge to instruction and goes about as impetus the administration contributing generous piece of their national salary in training which is still beneath $26 \%$ budgetary portion on training that was prescribed by UNDP. Along these lines, training as a noteworthy contributory factor to monetary development through advancement of human beneficial limit of the country isn't impossible to miss to Pakistan, it is a worldwide marvel.

It is clear that under-interest in instruction will compel the abilities, information, and competency of the general population of the nation and prompt financial hindrance of such nation. This is because of the way that overlooking interest in training would mean disregarding significant part of human capital improvement in the development procedure, and prompts bringing down the profitable limit of such economy. In the light of these, there are diverse issues which will fill in as hindrances during the time spent interest in instruction in Pakistan, these incorporates: Problem of whimsical and inappropriate subsidizing of training with its impact on deficient and old books, not well prepared research center and so on. Little school enrolment 
at all level of training in Pakistan which might be because of religious and social conviction and sexual orientation affectability. Defilement with respect to top training authorities siphoning the dispensed store to training segment. Changing in the need of the administration and the political pioneers bargaining instruction with different parts. Conflicting income from the income base of the country that achieves disappointment in the execution of the instructive arrangement.

This investigation will prefer some strategy suggestion for both private people and government to enhance interest in instruction in Pakistan. As this establish the significant methods for accomplishing both medium and long haul financial objective set up by countries and the different universal associations. The end that would be drawn and the proposal that would be made will fill in as a guide for strategy creators in perceiving the significance of suitable interest in training as articulated by UNDP that at the very least $26 \%$ of yearly budgetary arrangement ought to be focused on instruction area. At last, this examination study will assist us with determining the veracity of the Association of Staff Union Of University of Pakistan (ASUU's) guarantee and unsettling which came about to a half year mechanical activity, that Federal legislature of Pakistan should Increase Funding (Budgetary designation to training) as the way to rescue our instruction framework from being further spoiled; convey our nearly seized economy by non-natives and to elevate Pakistan economy to the following level.

The investigation of interest in instruction is brought together in human capital methodology. Human capital is the term market analysts frequently use for instruction, as and human limits that can raise efficiency when expanded. A similarity is made to regular interests in physical capital: After an underlying speculation is made, a surge of higher future salary can be created from extension of instruction or expanding interest in training. Therefore, a rate of return can be reasoned and contrasted with comes back with different speculations. Putting resources into training additionally contribute straightforwardly to prosperity, yet the human capital methodology centers around their aberrant capacity to expand capacity by expanding wages.

There are many studies on the impact of investment in human on economic growth ( Harbison, 1973; Schultz, 1960; Schultz 1961a ; Barro1991; Romer ; 1990b; Banhabib \& Spiegel, 1994; Bakar et al., 2014; Azam \& Ahmad, 2015; Khan et al., 2014; 2015a,b; 2016; 2017; Azam \& Khan, 2018; Rehman et al., 2018; Bakar \& Azam, 2018; Shah et al., 2018).

This article aims to find the impact of investment in education sector on economic growth of the Pakistan. This section presented a brief introduction 
and literature, the next section presents methodology and estimation techniques, finally results and conclusion are discussed in the last section.

\section{Data and Methodology}

The following model is used in this study, which has also been used by several prior studies including (Banhabib \& Spiegel, 1994; Bakar et al., 2014; Azam \& Ahmad, 2015; Muhammad 2015; Muhammad et al., 2017; Azam \& Khan, 2018; Rehman et al., 2018; Bakar \& Azam, 2018; Khan et al., 2018).

$\mathrm{GDP}=\alpha 0+\alpha 1 \mathrm{ExpEdn}+\alpha 2 \mathrm{SE}+\alpha 3 \mathrm{GCF}+\varepsilon$

Where is GDP is gross domestic product per capita income, ExpEdn is expenditures on education, GCF is gross capital formation, and $\varepsilon$ is error term.

The data source is World Development Indicators (2018), the selected time frame is from 1980 to 2018 . The selected data is taken annually. We use the simple OLS technique because all the variables are stationary at level. The employed log-linear regression model to get the best result. We transformed the dependent variable to log to remove the trendiness from the data and get better results. The dependent variable is GDP Gross Domestic Product which is the proxy of growth rate in the Pakistan economy, ExpEdn is the independent variable stands for Expenditure on education as \% of total Govt. spending (\%), SE stands for gross school enrollment, primary and secondary, and GCF stands for total capital formation (\% of GDP).

\section{Results and Discussion}

The estimated results are presented in the below Table 1. It is evident from Table 1 that all our obtained empirical results are statistically significant except ExpEdn variable, based on the t-statistics, p-value, high $\mathrm{R}^{2}$ which is found to be 0.86 and adjusted $\mathrm{R}^{2} 0.85$ values. The school enrolment (SE) co-efficient is found to be 2.91, the standard error of the same variable is 0.552 Likewise, the $t$ statistic is 5.2831 and the probability value is 0.0000 found to be highly significant. Similarly, the total Capital Formation (GCF) co-efficient is found to be 0.14 and the standard error is 0.0314 and the probability value is found 0.0001 which showed a positive and significant influence on growth in Pakistan. The co-efficient of expenditure on education (ExpEdn) is 0.01, the standard error of the same variable is 0.025 and t-statistic is found to be 0.6045 and the probability value is 0.5501 which is insignificant in tour analysis but its positive sign 
justify the theory indicates that as the investment in the education sector increases leads it to a positive contribution to the development of the economy.

The school enrollment is highly significant at $1 \%$ and shows that a $1 \%$ change in School enrollment can increase the Pakistan economic growth by 2.91 units. The school enrollment has also a positive significant influence on growth of Pakistan's economy and is highly significant at $1 \%$. An increased of $1 \%$ in Gross capital formation leads to increased growth of Pakistan by 0.14 units and a highly significant at $1 \%$ which shows that increase investment in the physical capital leads to increase in the growth of Pakistan's economy. The $\mathrm{R}^{2}$ is the goodness of fit, the high value of $\mathrm{R}^{2}$ near to 1 show that the model is well fitted. The $\mathrm{R}^{2}$ is 0.86 which shows that our model is fitted well. Overall results exhibit that investment in education sector positively contributed to the national economic development of Pakistan.

\section{Table 1: Least Square Regression Results}

\begin{tabular}{|l|c|c|c|c|}
\hline & Co efficient & Std. Error & t-Statistic & Prob \\
\hline Constant & 25.411 & 0.7147 & 35.555 & 0.0000 \\
\hline ExpEdn & 0.01 & 0.025 & 0.6045 & 0.5501 \\
\hline SE & 2.91 & 0.552 & 5.2831 & 0.0000 \\
\hline GCF & 0.14 & 0.0314 & 4.538 & 0.0001 \\
\hline $\mathrm{R}^{2}$ & 0.868 & & & \\
\hline adj. $\mathrm{R}^{2}$ & 0.8550 & & & \\
\hline
\end{tabular}

Note: The dependent variable is real GDP Per capita

\section{Conclusion}

The estimated results showed that the investment in capital formation and education sector leads to increase the economic growth in Pakistan. Time series data was taken for the period of 1980 to 2018. The empirical results showed a positive and a significant impact of investment in education sector on economic growth in Pakistan which is an indication for policy makers to concentrate on education and research and development sector to boost the economy. Moreover to enhance Pakistan growth performance, it is important to focus on macroeconomic stability by applying sound economic policy. The empirical results demonstrated that investment in education matter a lot, for growth of the economy. Thus, the objectives of macroeconomic policies must be increasing investment through FDI and 
boost physical sector and education sector. In Pakistan Political instability is a serious issue, as security and political stability plays a vital role in attracting foreign direct investment and retaining human $\&$ physical capital. Therefore, it is highly recommended that further research be done to find among other things the relationship between labor and long-run growth. Investment on human capital need to be improved along with the Physical Capital since it has the greatest impact on economic growth.

\section{References}

Azam, M. \& Ahmad, M. A., (2015). Role of human capital and foreign direct investment in promoting economic growth: evidence from Commonwealth of Independent States. International Journal of Social Economics, 42(2), 89-111.

Azam, M. \& Khan, S. (2018). Inflation and the economic growth: evidence from Five Asian Countries. Pakistan Journal of Applied Economics, 28(2), 235-252.

Bakar, N.A.A., \& Azam, M. (2018). Estimating demand for infrastructure in northern states of Malaysia. Proceedings of 135th ISERD International Conference, Kuala Lumpur, Malaysia, 18th -19th October 2018, 1-6.

Bakar, N. A A., Haseeb, M., \& Azam, M., (2014). The nexus between education and economic growth in Malaysia: cointegration and TodaYamamoto causality approach. Actual Problems of Economics, 12(162), 131-141.

Banhabib, J., \& Spiegel, M. M. (1994). The role of human capital in economic development Evidence from aggregate cross-country data. Journal of Monetary Economics, 34, 143-173.

Barro, R. (1991). Economic growth in a cross section of countries, Quarterly Journal of Economics, 106, 407-444.

Harbison, F.H. (1973). Human resources as the wealth of nations. New York: Oxford University Press.

Khan, F., Fauzee M.S. O. \& Daud, Y., (2017). Education, teacher training, problems and challenges: A comparative study between India and Pakistan. Gomal University Journal of Research, (Special Issue II), 112).

Khan F., \& Haseeb, M. (2017). Analysis of teacher training education program: a comparative study of Indonesia, Malaysia and Pakistan. Paradigms, 11(1), 13-17.

Khan, F., Fauzee M.S. O. \& Daud, Y., (2016). Qualitative analysis of the teacher's performance in private and public sector schools: A 
developing country's experience. Educational Research International, 59(4), 33-39.

Khan, F., Fauzee M.S. O. \& Daud, Y., (2015). Significance of teachers and education in promoting national economic development: a case study of Pakistan. Asian Social Science, 11(12), 290-296.

Khan, F., Javeria U., \& Numan, M. (2015). Education, foreign direct investment and socio-economic development-A review. Abasyn Journal of Social Sciences, 7 (2), 269-277.

Khan, F., Fauzee M.S. O. \& Daud, Y., (2014). A cursory review of the importance of teacher training: a case study of Pakistan. Middle-East Journal of Scientific Research, 21 (6), 912-917.

Khan, A.Q., Hafeez, M. H., Saleem, N., \& Azam, M. (2018). Exploring the impact of financial development on inequality: evidence from Three Asian Countries. Review of Economics and Development Studies, 4(2), 334-355.

Mankiw, N. G. (1998). teaching the principles of economics. Eastern Economic Journal, 24(4), 519-524. URL http://www.jstor.org/stable/40325896.

Muhammad, A., (2015). The role of migrant workers' remittances in fostering economic growth: The four Asian developing country's experiences. International Journal of Social Economics, 42(8), 1-18.

Muhammad, A., Khan, A. Q., \& Bakhtyar, B., (2017). Surveying sources of economic growth: empirical evidence from Malaysia. Problems and Perspectives in Management, 15(4), 114-123.

Rehman, Z, Tariq, M, \& Azam, M. (2018). The role of human capital in economic development in the selected Central Asian countries. The Dialogue, XIII(03), 235-244.

Romer, P. (1990b). Human capital and growth: theory and evidence, Carnegie Rochester Conference Series on Public Policy, 32, 251-286.

Schultz, T. (1961a). Investment in Human Capital, American Economic Review, 51 (1), 1-17.

Schultz, T. (1960b). Capital formation in education, Journal of political Economy. 68 (4), 571-583.

Shah, A. A., Irshadullah, H.M., \& Khan, F. (2018). The factors affecting students' academic performance at Abdul Wali Khan University Mardan, Pakistan. Research Journal of Education, II( I), 59-67.

World Development Indicators (2018), World Bank. 